\title{
薬歴簿からみた尿路感染についての考察
}

\author{
大 沢 友二 \\ 千鳥橋病院薬局*
}

\section{Urinary Infections in Drug History}

\author{
YUJI OSAWA \\ Pharmacy, Chidoribashi Hospital*
}

(Received March 10,1978)

\begin{abstract}
Annual change in bacteria detected in urinary infections and their sensitivity to antibacterial agents in 3-year drug history was studied for selection of the drugs of choice. Grampositive bacteria decreased in the 3-year period, while gram-negative organisms (mostly E. coli, Klebsiella, Proteus, P. aeruginosa, Enterobacter) increased markedly. E. coli increased resistance to AB-PC, Klebsiella to $\mathrm{CEZ}$, and $\mathrm{P}$. aeruginosa to $\mathrm{GM}$; and E. coli, Klebsiella and Enterobacter increased sensitivity to $\mathrm{CP}$. The drugs of first choice thus selected for controlling the 5 species of bacteria were : CEX, NA, CEZ and GM for E. coli ; CEX, NA and CEZ for Klebsiella ; CB-PC, AMK and SB-PC for P. aeruginosa ; NA, TC and GM for Enterobacter. Then, sensitivity to $\mathrm{CB}-\mathrm{PC}$ and SB-PC disks of $\mathrm{P}$. aeruginosa and Proteus detected in the urine samples in 3 years was compared. Proteus showed no difference in sensitivity to the two agents, while P. aeruginosa was more sensitive to SB-PC than to CB-PC. It is, therefore, necessary to study the factors in the difference and to compare clinical usefulness of the two drugs.
\end{abstract}

尿からの分離菌や尿路感染の起炎菌などは, 尿路疾忠 の変遷や薬物療法の変化などによって年々かわって行く といわれている. その傾向を知って臨床の場で活用する ことが必要である.

当院ではすでに 7 年間の病棟活動で集積された薬歴簿 をもっているが，今回はこの 3 年間の尿路感染症患者薬 歴簿を,

(1) 3 年間の検出菌の特徵之年次変化

(2)グラム陰性菌 5 菌種の抗生物質, 化学療法剂の感性 率と年度別変化, 及びその成績をもとにした当院の薬剤 選択.

(3) 3 年間で検出された Proteus, P. aeruginosa に ついてのデスクによる CB-PC, SB-PC の感受性比較を 考察したので報告する.

\section{1. 対象患者}

1975年 1 月から77年12月までの入院患者

1975年: 35症例, 11菌種, 128株

1976年 : 38症例, 12菌種, 140株

1977年: 41 症例, 12 菌種, 154株

* 福岡市博多区干代 5 丁目 14-24；14-24, Chiyo 5chome, Hakata-ku, Fukuoka-shi, 812 Japan

\section{2. 調查方法}

検出菌: 定量培養 $10^{5}$ 個以上の菌数を有意とした. 採取方法: 導尿, 中間尿, カテーテル留置尿.

デスク：栄研トリデスク 14 種

Tetracycline(TC), Chloramphenicol (CP), Streptomycin (SM), Kanamycin (KM), Gentamicin (GM), Amikacin (AMK), Cephalexin (CEX), Cephazolin (CEZ), Ampicillin (AB-PC), Carbenicillin (CB$\mathrm{PC})$, Sulbenicillin (SB-PC), Colistin (CL), Nalidixic acid (NA), Sulfisoxazole (SA)

判定：デスク\#以上を感受性ありとした.

培地: BTB 培地, 血液カンテン培地, 110培地.

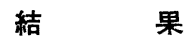

\section{1） 3 年間の菌别検出割合}

年度別検出株数で菌別 検 出割合を検討すると, Staphylococcus, Enterococcus, 真菌は年々検出率が低下 した.グラム陰性菌は検出率が年々増加した.

グラム陰性菌の菌別検出内訳 (図 1 参照) は, E. coli が最も多かった. Klebsiella は增加傾向にあり, Proteus は77年大幅に減少した. P. aeruginosaは77年に減少し 
たが，検出比率は大きかった. Enterobacter は77年に 急増した.これら 5 菌種を加えた検出率は年々增加した。 その他少数ながら Morganella, Citrobacter が 3 年間 を通じ検出された。最近，注目されている Seratia は 76年に 1 株検出されただけであった。

E. coli, Klebsiella, Proteus, P. aeruginosa,

Enterobacter の 5 菌種について年度別症例検出率（図 2 参照）でみると，E. coli が最も多く 3 年間を通じ症 例の半数に検出された. Klebsiella, P. aeruginosa は 年々検出率が增加した. Proteus は77年に減少したが， 検出比率は大きかった。 Enterobacter は 77 年に急增 した。

2）莱㕁感受性と年度别変化（表 1 参照）

E. coli, Klebsiella, Proteus, P. aeruginosa, Enterobacter の 5 菌種について感受性を検討した。

(1) E. coli : GM, CEZ, CEX, NA が 3 年間高感性 率であった. 77 年に $\mathrm{AMK}$ は全て感性であり, CPは感 性率が增加した。 AB-PC， TC は耐性が增加傾向にあ った。

(2) Klebsiella : CEX, CEZ, CL, GM は高感性率で あったが，CEZ は77 年耐性が大幅に増加した。 77 年

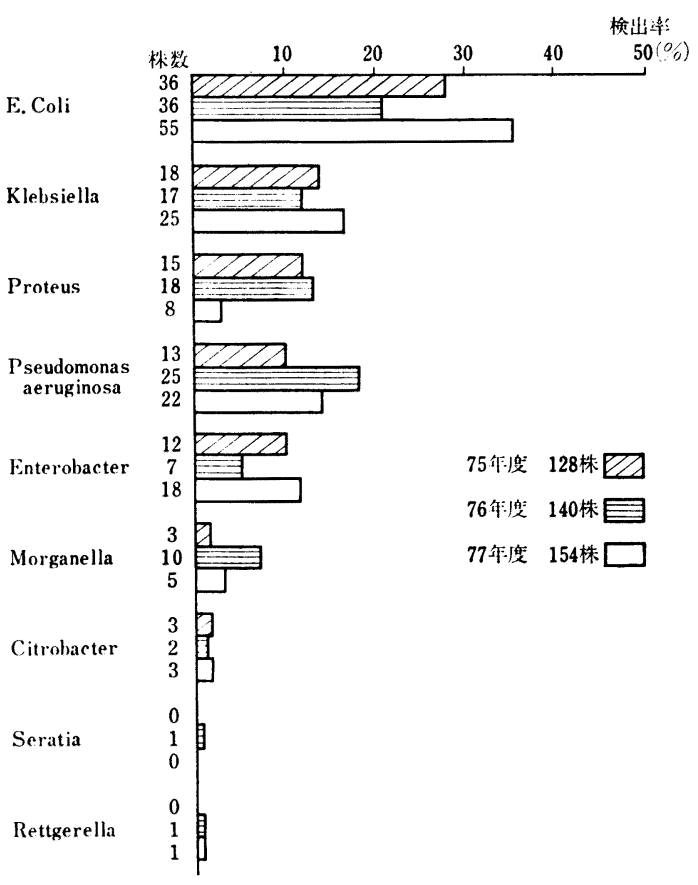

図1．総株数あたりの菌别検出率

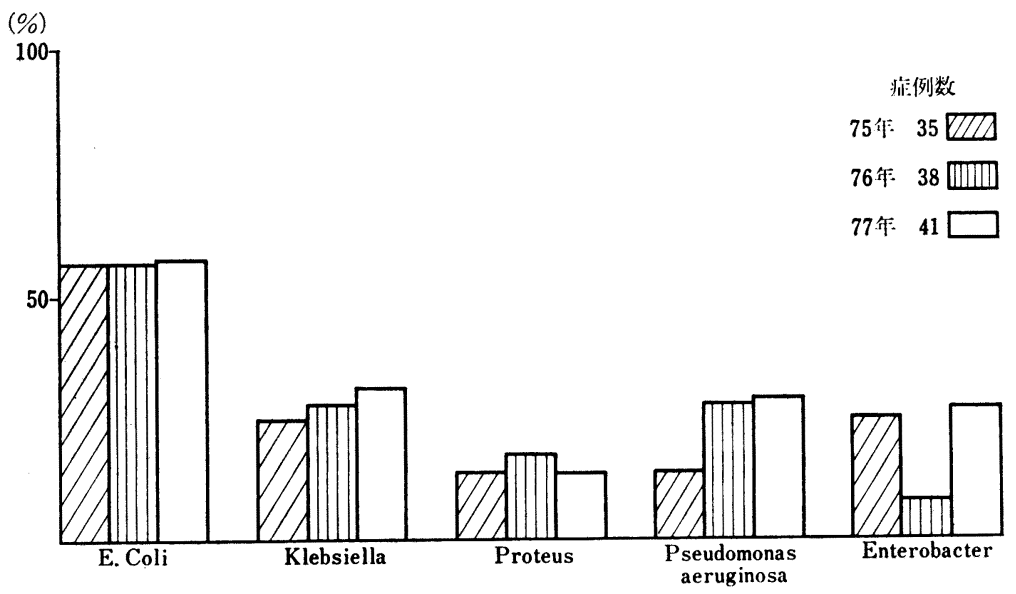

図2，5菌種年度别症例検出率

飞 AMK は全て感性であり, CP は感性率が增加した。

(3) Proteus : GM は高感性率を示した. CEZ, CEX は低感性率であった。

(4) P. aeruginosa : CL は高感性率を示し, 77 年 $\mathrm{AMK}$ が全て感性であった. CB-PC, SB-PC は中程度の感性 率であり，GM は耐性が急速に增加した。

(5) Enterobacter : CP, GM, TC が高感性率を示し, 77年CL，NA の感性率增加が目立った。 CEX，CEZ は
高耐性率であった。

3）デスク法による CB-PC, SB-PC の照受性比校 （図 3 ，図 4 参照）

Proteus で CB-PC, SB-PC のデスク感受性相関につ いてみると, 両薬凧で感受性 (-) が SB-PC 10 株, CB-PC 11 株あり，感受性のある株で両薬風間飞差のな いもの11株であった，SB-PC 優位は 4 株であり, 内訳 は感受性卅の差が 1 株, 十の差が 3 株であった. CB-PC 
表 1.5 菌種の年度別薬剤感性率（カッコ内株数）

\begin{tabular}{|c|c|c|c|c|c|c|c|c|c|c|c|c|c|c|c|}
\hline 菌 & & $C$ & & & ho & & & rot & & & & & & rat & er \\
\hline . & 75 & 76 & 77 & 75 & 76 & 77 & 75 & 76 & 77 & 75 & 76 & 77 & 75 & 76 & 77 \\
\hline TC & $\begin{array}{c}\% \\
56 \\
(36)\end{array}$ & $\begin{array}{c}\% \\
43 \\
(30)\end{array}$ & $\begin{array}{c}\% \\
38 \\
(52)\end{array}$ & $\begin{array}{c}\% \\
94 \\
(18)\end{array}$ & $\begin{array}{c}\% \\
41 \\
(17)\end{array}$ & $\begin{array}{c}\% \\
64 \\
(25)\end{array}$ & $\begin{array}{c}\% \\
60 \\
(15)\end{array}$ & $\begin{array}{c}\% \\
22 \\
(18)\end{array}$ & $\begin{array}{c}\% \\
38 \\
(8)\end{array}$ & - & $\%$ & $\%$ & $\begin{array}{c}\% \\
42 \\
(12)\end{array}$ & $\begin{array}{c}\% \\
71 \\
(7)\end{array}$ & $\begin{array}{c}\% \\
65 \\
(17)\end{array}$ \\
\hline $\mathrm{CP}$ & $\begin{array}{c}59 \\
(36)\end{array}$ & $\begin{array}{c}57 \\
(30)\end{array}$ & $\begin{array}{c}91 \\
(22)\end{array}$ & $\begin{array}{c}94 \\
(18)\end{array}$ & $\begin{array}{c}59 \\
(14)\end{array}$ & $\begin{array}{c}90 \\
(10)\end{array}$ & $\begin{array}{c}47 \\
(15)\end{array}$ & $\begin{array}{c}78 \\
(18)\end{array}$ & $\begin{array}{c}33 \\
(3)\end{array}$ & - & - & - & $\begin{array}{c}33 \\
(12)\end{array}$ & $\begin{array}{c}71 \\
(7)\end{array}$ & $\begin{array}{c}80 \\
(5)\end{array}$ \\
\hline $\mathrm{SM}$ & & $\begin{array}{c}10 \\
(29)\end{array}$ & $\begin{array}{c}10 \\
(21)\end{array}$ & $\begin{array}{c}50 \\
(18)\end{array}$ & $\begin{array}{c}18 \\
(17)\end{array}$ & $\begin{array}{c}20 \\
(10)\end{array}$ & $\begin{array}{c}36 \\
(14)\end{array}$ & $\begin{array}{c}78 \\
(18)\end{array}$ & $\begin{array}{c}67 \\
(3)\end{array}$ & - & - & - & $\begin{array}{c}18 \\
(11)\end{array}$ & $\begin{array}{c}27 \\
(6)\end{array}$ & $\begin{array}{c}0 \\
(4)\end{array}$ \\
\hline $\mathrm{KM}$ & $\begin{array}{c}62 \\
(34)\end{array}$ & $\begin{array}{c}77 \\
(30)\end{array}$ & $\begin{array}{c}71 \\
(21)\end{array}$ & $\begin{array}{c}59 \\
(17)\end{array}$ & $\begin{array}{c}59 \\
(17)\end{array}$ & $\begin{array}{c}30 \\
(16)\end{array}$ & $\begin{array}{c}33 \\
(15)\end{array}$ & $\begin{array}{c}89 \\
(18)\end{array}$ & $\begin{array}{c}67 \\
(3)\end{array}$ & . & - & - & $\begin{array}{c}42 \\
(12)\end{array}$ & $\begin{array}{c}33 \\
(6)\end{array}$ & $\begin{array}{c}20 \\
(5)\end{array}$ \\
\hline GM & $\begin{array}{c}97 \\
(33)\end{array}$ & $\begin{array}{c}93 \\
(30)\end{array}$ & $\begin{array}{c}85 \\
(55)\end{array}$ & $\begin{array}{c}83 \\
(18)\end{array}$ & $\begin{array}{c}75 \\
(16)\end{array}$ & $\begin{array}{c}78 \\
(23)\end{array}$ & $\begin{array}{c}80 \\
(15)\end{array}$ & $\begin{array}{c}89 \\
(18)\end{array}$ & $\begin{array}{c}88 \\
(8)\end{array}$ & $\begin{array}{l}100 \\
(13)\end{array}$ & $\begin{array}{c}40 \\
(25)\end{array}$ & $\begin{array}{c}45 \\
(20)\end{array}$ & $\begin{array}{c}50 \\
(12)\end{array}$ & $\begin{array}{c}71 \\
(7)\end{array}$ & $\begin{array}{c}61 \\
(18)\end{array}$ \\
\hline AMK & $(0)$ & $(0)$ & $\begin{array}{l}100 \\
(12)\end{array}$ & $(0)$ & $(0)$ & $\begin{array}{l}100 \\
(9)\end{array}$ & - & 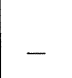 & - & $(0)$ & $(0)$ & $\begin{array}{l}100 \\
(3)\end{array}$ & - & - & - \\
\hline$B-P C$ & $\begin{array}{c}41 \\
(34)\end{array}$ & $\begin{array}{c}23 \\
(30)\end{array}$ & $\begin{array}{c}35 \\
(55)\end{array}$ & $\begin{array}{c}0 \\
(18)\end{array}$ & $\begin{array}{c}0 \\
(17)\end{array}$ & $\begin{array}{c}0 \\
(23)\end{array}$ & $\begin{array}{c}40 \\
(15)\end{array}$ & $\begin{array}{c}28 \\
(18)\end{array}$ & $\begin{array}{c}63 \\
(8)\end{array}$ & - & - & - & $\begin{array}{c}8 \\
(12)\end{array}$ & $\begin{array}{c}14 \\
(7)\end{array}$ & $\begin{array}{c}0 \\
(17)\end{array}$ \\
\hline$B-P C$ & - & - & - & $\begin{array}{c}0 \\
(12)\end{array}$ & $\begin{array}{c}0 \\
(11)\end{array}$ & $\begin{array}{c}0 \\
(18)\end{array}$ & $\begin{array}{c}43 \\
(14)\end{array}$ & $\begin{array}{c}50 \\
(8)\end{array}$ & $\begin{array}{c}50 \\
(4)\end{array}$ & $\begin{array}{c}45 \\
(11)\end{array}$ & $\begin{array}{c}40 \\
(20)\end{array}$ & $\begin{array}{c}63 \\
(19)\end{array}$ & - & - & - \\
\hline S B-P C & - & - & - & $\begin{array}{c}0 \\
(14)\end{array}$ & $\begin{array}{c}0 \\
(11)\end{array}$ & $\begin{array}{c}0 \\
(18)\end{array}$ & $\begin{array}{c}64 \\
(14)\end{array}$ & $\begin{array}{c}50 \\
(8)\end{array}$ & $\begin{array}{c}50 \\
(4)\end{array}$ & $\begin{array}{c}91 \\
(11)\end{array}$ & $\begin{array}{c}75 \\
(20)\end{array}$ & $\begin{array}{c}58 \\
(19)\end{array}$ & - & - & - \\
\hline CEX & $\begin{array}{c}82 \\
(33)\end{array}$ & $\begin{array}{c}67 \\
(30)\end{array}$ & $\begin{array}{c}62 \\
(55)\end{array}$ & \begin{tabular}{|c}
88 \\
$(17)$
\end{tabular} & $\begin{array}{c}63 \\
(16)\end{array}$ & $\begin{array}{c}74 \\
(23)\end{array}$ & $\begin{array}{c}67 \\
(15)\end{array}$ & $\begin{array}{c}35 \\
(17)\end{array}$ & $\begin{array}{c}38 \\
(8)\end{array}$ & - & - & - & $\begin{array}{c}17 \\
(12)\end{array}$ & $\begin{array}{c}14 \\
(7)\end{array}$ & $\begin{array}{c}22 \\
(18)\end{array}$ \\
\hline CEZ & $\begin{array}{c}91 \\
(33)\end{array}$ & $\begin{array}{c}90 \\
(30)\end{array}$ & $\begin{array}{c}78 \\
(55)\end{array}$ & \begin{tabular}{|c}
72 \\
$(18)$
\end{tabular} & $\begin{array}{c}76 \\
(17)\end{array}$ & $\begin{array}{c}61 \\
(23)\end{array}$ & $\begin{array}{c}80 \\
(15)\end{array}$ & \begin{tabular}{|c}
33 \\
$(16)$
\end{tabular} & $\begin{array}{c}50 \\
(8)\end{array}$ & - & - & - & $\begin{array}{c}17 \\
(12)\end{array}$ & $\begin{array}{c}14 \\
(7)\end{array}$ & $\begin{array}{c}22 \\
(18)\end{array}$ \\
\hline CL & $\begin{array}{c}94 \\
(36)\end{array}$ & $\begin{array}{c}97 \\
(30)\end{array}$ & $\begin{array}{c}94 \\
(54)\end{array}$ & $\begin{array}{l}100 \\
(18)\end{array}$ & $\begin{array}{c}76 \\
(17)\end{array}$ & $\begin{array}{c}84 \\
(25)\end{array}$ & $\begin{array}{c}7 \\
(15)\end{array}$ & $\begin{array}{c}17 \\
(18)\end{array}$ & $\begin{array}{c}25 \\
(8)\end{array}$ & $\begin{array}{l}100 \\
(13)\end{array}$ & $\begin{array}{l}100 \\
(25)\end{array}$ & $\begin{array}{c}91 \\
(22)\end{array}$ & $\begin{array}{c}50 \\
(12)\end{array}$ & $\begin{array}{c}43 \\
(7)\end{array}$ & $\begin{array}{c}82 \\
(17)\end{array}$ \\
\hline NA & \begin{tabular}{|c}
75 \\
$(32)$
\end{tabular} & $\begin{array}{c}63 \\
(30)\end{array}$ & $\begin{array}{c}75 \\
(43)\end{array}$ & $\begin{array}{c}41 \\
(17)\end{array}$ & $\begin{array}{c}25 \\
(16)\end{array}$ & $\begin{array}{c}32 \\
(22)\end{array}$ & $\begin{array}{c}40 \\
(15)\end{array}$ & $\begin{array}{c}35 \\
(17)\end{array}$ & $\begin{array}{c}50 \\
(8)\end{array}$ & - & - & - & $\begin{array}{c}60 \\
(10)\end{array}$ & $\begin{array}{c}43 \\
(7)\end{array}$ & $\begin{array}{c}67 \\
(18)\end{array}$ \\
\hline S A & $\begin{array}{c}0 \\
(36)\end{array}$ & $\begin{array}{c}3 \\
(30)\end{array}$ & $\begin{array}{c}0 \\
(21)\end{array}$ & $\begin{array}{c}0 \\
(18)\end{array}$ & $\begin{array}{c}0 \\
(17)\end{array}$ & $\begin{array}{c}0 \\
(10)\end{array}$ & $\begin{array}{c}0 \\
(15)\end{array}$ & $\begin{array}{c}6 \\
(18)\end{array}$ & $\begin{array}{c}33 \\
(3)\end{array}$ & - & 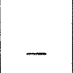 & & $\begin{array}{c}0 \\
(12)\end{array}$ & $\begin{array}{c}14 \\
(7)\end{array}$ & $\begin{array}{c}0 \\
(4)\end{array}$ \\
\hline
\end{tabular}
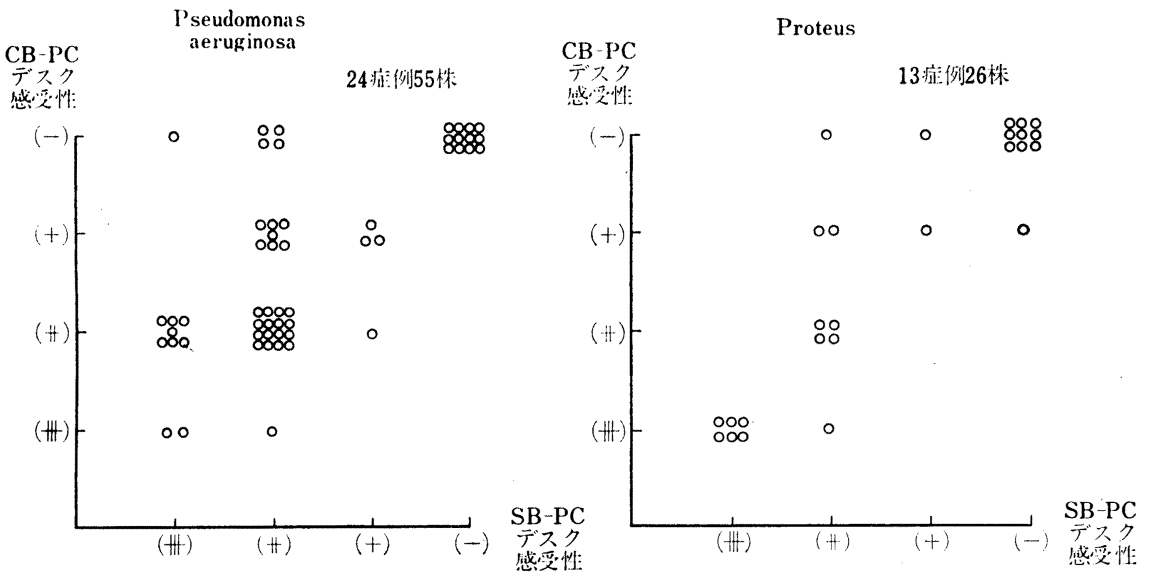

図 3. CB-PC・SB-PC 感受性テストについて

優位は 2 株で十の差であった。

感受性内訳は SB-PC は (H) が多く, CB-PC は (H)
が多かった。（州）と（H）を加えると，両薬剤はほぼ同 比率を示した。（一）もほぼ同比率であった。 

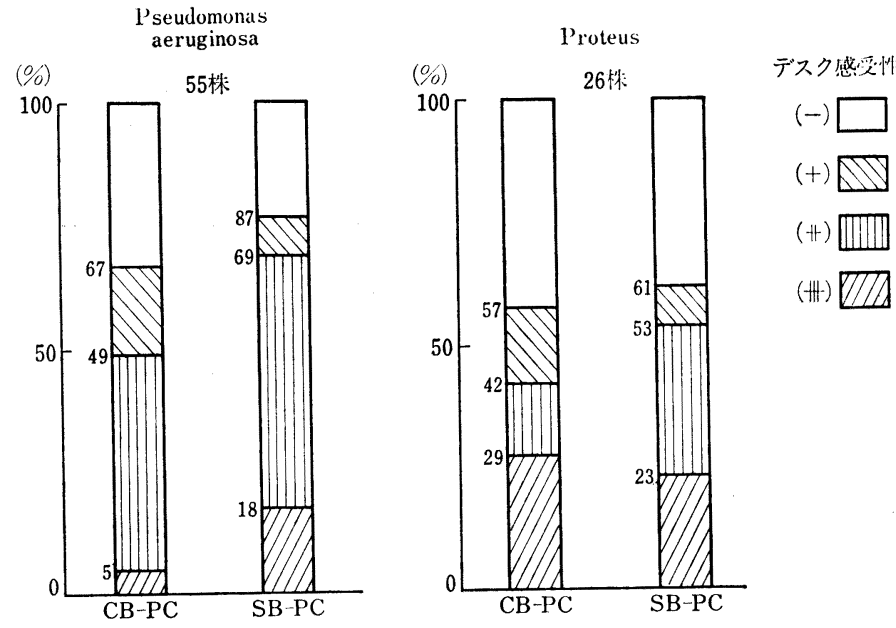

図 4. Pseudomonas aeruginosa, Proteus

CB-PC, SB-PC に対する感受性内訳

P. aeruginosa におけるデスク相関は，(一)が SB_ PC 12 株, CB-PC 17 株, 感受性のある株で感受性に差 のないもの 21 株であった. SB-PC 優位は 15 株あり，内 訳は\#の差が 5 株, 十の差が 10 株であった. CB-PC 優 位は十の差が 2 株であった。

感受性内訳は（卅）は SB-PC が多く，（H）は雨薬

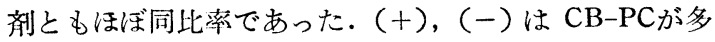
かった。

\section{考察}

3 年間の検出割合の特徵は, グラム陽性菌の低下, グ ラム陰性菌の増加であり，猪狩ら”報告と一致する が，松岡ら2の報告にみるグラム陽性菌の徐增傾向は当 病院ではみられなかった。 又，猪狩ら吕や松岡ら2)の報 告にみる Seratia の検出率增加はなかった。

年度每の E. coli, Klebsiella, Proteus, P. aeruginosa, Enterobacter の 5 菌種を総株数あたりと症例数での検 出率で対比すると, E. coli は株数, 症例数ともに検出 率が最も高く, 原因は AB-PC 耐性增加によると思われ る. Klebsiella, Enterobacter で症例数と株数の検出率 が増加した原因は，Klebsiella の AB-PC，NA 高耐 性, $\mathrm{CEZ}$ 耐性增加, Enterobacter の CEX, CEZ, AB-PC 高耐性にあったと考える.P. aeruginosa の株 数検出率低下, 症例検出率上昇の原因は, PC 系, Cephalosporin 系薬剂低感受性と CL, AMK 高感性率 によるものであり, Proteus の症例，株数検出率低下 の原因は GM 高感性率であったと考える.

薬剤別感受性の特徵を考察すると, CEZ の Klebsiella
耐性率は清水 ${ }^{3)}$ の報告に比べ高率であった。 GM で P. aeruginosa の急速な耐性增加は熊沢4) の報告と一致 した.CP の E. coli, Klebsiella, Enterobacter の77 年高感性率の原因は使用制限のためと考える。菌㭘出動 向は使用頻度の高い薬剤 (AB-PC, CEZ, CEX, GM, NA）の感受性変化に影響された。

つぎに尿路の主感染菌である 5 菌種 (E. coli，Klebsiella, Proteus, P. aeruginosa, Enterobacter)につい て感受性変化にもとづいて薬剤選択を考察した。（表 2 参照)

表 2 ，尿路感染にわける当病院での選択順位

\begin{tabular}{|c|c|c|c|c|c|}
\hline \multirow{2}{*}{ 闌 } & \multirow{2}{*}{ 種 } & \multicolumn{2}{|c|}{ 第一選 択 } & \multicolumn{2}{|c|}{ 第 …選択 } \\
\hline & & 経 口 & 射 & 経口 & 注 射 \\
\hline \multicolumn{2}{|c|}{ E. Coli } & CEX, NA & GM, CEZ & $\mathrm{CP}$ & $\begin{array}{c}\text { CP, CL } \\
\text { AMK }\end{array}$ \\
\hline \multicolumn{2}{|c|}{ Klebsiella } & CEX & GM, CEZ & CP & $\begin{array}{c}\text { CP, CL } \\
\text { AMK }\end{array}$ \\
\hline \multicolumn{2}{|c|}{ Proteus } & $\begin{array}{l}\mathrm{AB}-\mathrm{PC} \\
\mathrm{CB}-\mathrm{PC}\end{array}$ & $\begin{array}{c}\text { GM, SB-PC } \\
\text { CB-PC } \\
\text { AB-PC }\end{array}$ & & KM, SM \\
\hline \multicolumn{2}{|c|}{$\begin{array}{l}\text { Pseudomonas } \\
\text { aeruginosa }\end{array}$} & CB-PC & $\begin{array}{c}\text { SB-PC } \\
\text { CB-PC } \\
\text { AMK }\end{array}$ & & $\mathrm{CL}$ \\
\hline \multicolumn{2}{|c|}{ Enterobacter } & TC, NA & GM & $\mathrm{CP}$ & $\mathrm{CP}, \mathrm{CL}$ \\
\hline
\end{tabular}

当病院のデータと猪狩1)，黑田ら5) の報告を参考に 5 菌種に対する選択薬順位を定め, ベッドサイドで薬剤師 が医師に助言する場合の参考としている.

CB-PC, SB-PC のデスク感受性比較をみると, Proteus で CB-PC は (卅), SB-PC は (\#) が多い傾 
向にあるが，両薬剤は相関性を示し，仙田ら ${ }^{6)}$, 纠口ら の報告と一致した。しかし，水野ら ${ }^{8)}$ ，小酒州”9 9 蛝告 の $\mathrm{CB}-\mathrm{PC}$ 優位や小栗ら ${ }^{10)}$ の報告にみる SB-PC 優位は みられなかった。

P. aeruginosa の両薬剂デスク感受性は, SB-PC に優

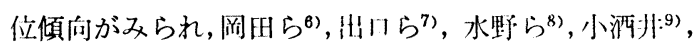

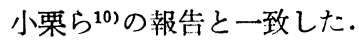

\section{結語}

菌検出割合は当院に护沙頻用抗生剂 (AB-PC, CEZ, CEX，GM，NA）の感受性、大きく影響された。特に Klebsiella, Enterobacter の検出率增加は, 頻用抗生剂 $\mathrm{AB}-\mathrm{PC}, \mathrm{CEZ}$ に対する低感性率が原因と思われる。 CB-PC, SB-PC のデスク感受性において, Proteus は 両薬剤間に相関がみられ，P. aeruginosaは SB-PC 優 位傾向であった。
文献

1) 猪特 淳: The Japanese Journal of Antibiotics, XXX-8, 596 (1977).

2) 大川光央, 折戸松男, 菅田敏明, 島村正喜, 岡所 明, 平野章治, 中下英以助, 黒田莱一: 泌尿器科 紀要, 23，493 (1977).

3）清水喜八郎：内科, 39, 1104 (1977).

4) 熊沢浄一：治療, 59, 41 (1977).

5) 松岡俊介, 神永陽一郎：臨床泌尿器科, 31,813 (1977).

6) 岡田 淳, 小酒井望, 小栗豊子：日本臨朋(別冊), 4, 3 (1976).

7) 出口浩一, 小田清次, 佐藤佳子, 中村 保, 横沢 教子: The Japanese Journal of Antibiotics, XXVIII-6, 786(1975).

8）水野加代, 清瀬 濶 : 臨牃と研究, 52, 3715 (19 75).

9) 小酒井望 : 新薬と臨床, 22, 1317 (1973).

10）小栗豊子, 吉村千秋 : 新薬と臨床, 22, 2113(1973). 